\title{
Economic Analysis and Performance of PV Plants: An Application in Kurdistan Region of Iraq
}

\author{
Olusola Bamisile $\mathrm{a}^{*}$, Foyin Olubiyo ${ }^{\mathrm{b}}$, Mustafa Dagbasi ${ }^{\mathrm{c}}$, Humphrey Adun ${ }^{\mathrm{c}}$ and \\ Ifeoluwa Wole-Oshoc
}

\begin{abstract}
${ }^{a}$ School of Mechanical and Electrical Engineering, University of Electronic Science and Technology of China, Chengdu, Sichuan P.R. China.
\end{abstract}

${ }^{\mathrm{b}}$ Engineering Management Department, Cyprus International University, Haspolat-Lefkosa, Mersin 10, Turkey.

cEnergy Systems Engineering Department, Cyprus International University, Haspolat-Lefkosa, Mersin 10, Turkey.

\begin{abstract}
In this study, photovoltaic (PV) technology development over the years is reviewed. The use of PV power plants to solve inadequate power supply in Kurdistan is also analysed. PV power application is one of the most developed renewable energy applications but still not commercialized in somw countries. In this paper, three different locations will be evaluated in Kurdistan for PV plant installation. The research will investigate the best location for PV plant installation in Kurdistan, check the viability of the proposed plants and compare the performance of a fixed and a double axis tracking system. A $10 \mathrm{MW}$ PV plant is developed and simulated based on economic terms. The results from the analysis shows that the simple payback period for a $10 \mathrm{MW}$ PV plant in all the locations considered is between 6.8 and 7.2 years. Also, the installation with two-axis tracking system gave the lowest simple payback period (6.8 years). The PV plant is viable considering other economic indicators like; IRR, NPV, annual life cycle savings and BCR. The yearly savings of the system for one of the locations considered is US $\$ 1,573,327$ with a dual axis tracking system. C2019. CBIORE-IJRED. All rights reserved
\end{abstract}

Keywords: Economic Analysis, Electricity, Energy, Kurdistan, Photovoltaics

Article History: Received: April 6, 2019; Revised: Sept 7, 2019; Accepted: Oct 2, 2019; Available online: Oct 30, 2019

How to Cite This Article: Bamisile, O., Olubiyo, P., Dagbasi, M., Adun, H. and Wole-Osho, I. (2019) Economic Analysis and Performance of PV Plants: An Application in Kurdistan Region of Iraq. International Journal of Renewable Energy Development, 8(3), 293-301 https://doi.org/10.14710/ijred.8.3.293-301

\section{Introduction}

Kurdistan region also known as Northern Iraq consist of three governorates; Erbil, Sulaymani, and Duhok. It also represents about $17 \%$ of total republic of Iraq with a land space of $73,618 \mathrm{~km}^{2}$ (Rashid 2014). The average daily solar energy potential for this region is $4.81 \mathrm{kWh} / \mathrm{m}^{2} /$ day and the yearly solar energy potential is estimated to be 6318.83 MJ/m²/yr (Abdul-Wahid, Mahdy, and Godu 2010). According to the Ministry of Planning there was a $579 \mathrm{MW}$ shortage in power supply in 2012 . Almost $82 \%$ of the total power demand in northern Iraq is provided by the government (Government 2013). The demand increases day by day, especially after the displacement of people, due to ISIS crisis in 2014. Although electricity production has increased over the years in Kurdistan, the consumer demands are yet to be met. Recently, the country had a grid-based transmission deficit of 7GW (Al-Karaghouli and Kazmerski 2010). Generator devices are the main supplement for electricity shortage in this region with about $90 \%$ of residential consumers using an estimated 3 TWh/yr from these devices. The cost implications of generators are 10 to 15 times more than the electricity obtained from the grid (IEA 2016). Demand for electricity is at its peak in summer with about $50 \%$ increase in average demand thereby causing an increase in electricity demand-supply gap (Kazem, Chaichan, and Kazem 2014). The advantages of PV technology include: reduction in petrol and natural gas usage for electricity generation, reduction in carbon dioxide emission and global warming effects. Development of more efficient PV panels, and the overall market share of PV technology has reduced its installation cost (Grover 2007). Nowadays, the efficiency of most commercial PV panels ranges from $15 \%$ and $20 \%$ (Kazem, Chaichan, and Kazem 2014). The disadvantages associated with the use of solar technologies includes; chemical effects of their material, effect on the aesthetic value in the buildings, degradation of lands etc. (Abolhosseini, Heshmati, Altmann 2014).

Literature has shown that one of the biggest problems of PV installations is the settlement of dust on solar panels. In a study carried out in Saudi Arabia (A.A.M 1978), it was concluded through experiments that there is as much as $11.5 \%$ decrease in the power production of a

\footnotetext{
* Corresponding author: boomfem@gmail.com
} 
PV installation. A comparative study of a small-scale solar PV power plant was carried out in Saudi Arabia (Rashwan, Shaaban, and Al-Suliman 2017). The new electricity tariffs (4.0 and 8.0 cents/kWh for governmental and commercial sectors respectively) is used. The equity PBP were found to be 8.2 and 14.1 years for the scenarios considered and the reduction in equity PBP is $41 \%$ when the electricity tariff is doubled. About $70 \mathrm{tCO}_{2}$ is saved with this project. The third scenario considered the use of grid electricity (73\%) and PV (27\%). While the equity PBP increased to 21.7 years, $23 \mathrm{tCO}_{2}$ is saved. A recent study in Tabass-Iran worked on optimum tilt and decline (Khorasanizadeh, Mohammadi, and Mostafaeipour 2014). The optimum tilt, monthly varies in June/July between $0^{\circ}$ and $64^{\circ}$ in December. The yearly optimum tilt was concluded to be $33.36^{\circ}$. $32^{\circ}$ and $10^{\circ}$ tilt angles were recommended. The performance of a $200 \mathrm{KWp}$ grid connected PV system in the optimal inclination and orientation suggested Koya city has the best performance (Abdulrahman, Abdullah, and Danial 2014). The study concluded that the yearly average energy is 5.14 $\mathrm{kWh} / \mathrm{m}^{2} /$ day, and by installing PV Panels optimally, this becomes $5.79 \mathrm{KWh} / \mathrm{m}^{2} /$ day.

Kurdistan region is one of the most peaceful developed regions in the country; nevertheless, the region is faced with serious electricity challenge. Currently, this region has inadequate power supply and rural areas have little or no access to electricity. Also, there is no grid connected or standalone large-scale PV plants in this region. In this research the use of a $10 \mathrm{MW}$ PV plant to generate electricity in Kurdistan region will be analysed. The economic benefits of this installation and its viability is the main aim of this study. This research will evaluate the use of PV plants in the Kurdistan as an alternative to fossil fuel for electricity generation. The research's significance is embedded in the evaluation of a sustainable and renewable source of energy and its viability in this region. The research will also give a better understanding about the potential of photovoltaic plant as a means of solving power shortage problem. A detailed performance and economic analysis of PV plant installations in this region will be done. Fixed and double axis PV plant technology will be considered. This write-up is divided into five sections. With a brief introduction in this section, section two reviews the development of PV plants over the years. Section three give the details of the research methodology and all the parameters used for the simulation are defined. The results and conclusions from this study are given in section four and five respectively.

\section{PV Plant Development Over the Years}

PV plant development has evolved over the years with recent studies focusing on optimal performance, casestudy, hybrid and cost analysis of PV applications. Sayedus et al (2016) used HOMER and RETScreen to propose a model for assessing RE systems (with focus on power systems providing electricity) (Salehin et al. 2016). The optimized system sizing based on the results from HOMER comprised of $51 \mathrm{~kW}$ of wind turbine, $62 \mathrm{~kW}$ of PV arrays and $9 \mathrm{~kW}$ Diesel generator for both (Wind and PV) systems. The Equity PBP, initial cost, GHG emission reduction for Wind-diesel and Solar PV-Diesel energy systems are 11.2 years, $\$ 347,859,42.9 t \mathrm{CO}_{2}$ and 5.4 years,
$\$ 234,267$, 54.3t $\mathrm{CO}_{2}$ respectively. Dihrab and Sopian (2010), studied the electricity generation using a solar/wind hybrid system in three cities in Iraq (Dihrab and Sopian 2010). Results from the modelling showed that solar and wind hybrid system is an effective system for electricity generation in rural areas of Iraq. Bousetta et. al. (2017), considered the pre-viability of a hybrid microgrid system in Morocco. Their results showed that coupling PV panels and wind turbines is the optimal solution for all studied areas with the exception of those in the east which are characterized by low average wind speed during the year (Boussetta et al. 2017).

Techno-economic modelling of PV systems help in the exploration PV potential. Al-Karaghouli, and Kazmerski (2010), analyzed the economic and technical feasibility of installing PV plant in a clinic in the rural part of Iraq. The calculation showed that the optimal system cost was US\$ 50,700 , while the net present cost and electricity cost were US\$ 60,375, and US\$ $0.238 / \mathrm{kW} h$ respectively (AlKaraghouli and Kazmerski 2010). This is efficient in terms of technical and economic analysis. Akinyele (2017), presents the techno-economic design and performance analysis of a nanogrid system. The analysis was done on five neighbouring houses, in Gwagwalada-Abuja, Nigeria. The possibility of using different energy configurations (solar nanogrid (SNg), diesel nanogrid (DNg), solar/diesel nanogrid (SDNg), solar/wind nanogrid (SWNg) and solar/wind/diesel nanogrid (SWDNg) systems) were explored. Results reveal that $5-14.5 \mathrm{~kW} \mathrm{SNg}$ can meet the users' demand of $12.5-36.5 \mathrm{kWh} / \mathrm{d}$ (D. Akinyele 2017). The techno-economic feasibility of installing a wind/PV hybrid system in a village in Saudi Arabia was considered in another study (Rehman et al. 2012). The energy requirement of the village was $17,043.4 \mathrm{MWh} / \mathrm{yr}$ of AC primary load, of which the wind-PV-diesel hybrid was able to meet, $4.1 \%$ energy in excess. The wind turbines contributed $4713 \mathrm{MWh}$ annually, while the solar PV added 1653.5MWh.

Furthermore, Patil et al., (2017), compared the technical and economic feasibility of solar PV systems with battery storage at a capacity of $50 \mathrm{kWe}$, solar thermal energy storage (TES) and solar organic Rankine cycle (sORC). Five performance indicators namely; capital cost, levelized cost of electricity (LCEO), capacity utilization factor (CUF) and energy wasted, were used to check the feasibility of the systems. The results indicate that in order to achieve minimum LCOE, the operational zones of the two technologies should differ in terms of storage requirement (Patil et al. 2017). An economic feasibility study in Chile about residential and commercial PV technology showed that the country has a good solar potential (Ram?rez-Sagner et al. 2017). The internal rate of return (IRR) for all the locations considered are higher than 5\%/yr. A retrofit techno-economic analysis of Canadian buildings with PV and BIPV/T (building integrated photovoltaic/thermal) was studied in (Asaee et al. 2017). The study predicts the GHG emission reduction, tolerable capital costs and energy savings for regions across Canada. BIPV/T system retrofit yields 17\% GHG emission reduction and $18 \%$ energy savings, while PV system yields 5\% GHG emission reduction and 3\% energy savings.

Another study proposed a small $(54.15 \mathrm{~kW})$ off-grid solar photovoltaic power generation for communities. 
Environmental analysis, life cycle emission and energy analyses of the system were the focus of the research (Akinyele 2017). Using the system is feasible with an energy payback period of 5.7 years over a lifetime analysis of 25 years. Results from the study also showed that battery has a life cycle emission and energy impact due to its relatively short lifespan. Proposing an economical and optimized design for electricity generation using hybrid energy source PV/Biomass for an agricultural farm and a residential community centred was the aim of one the studies (Shahzad et al. 2017) reviewed. This analysis compares the performance of the system and shows that system is techno economically viable based on the net present cost and cost of energy.

In another study by Ruifeng et al (2013), a yearlong performance analysis was done on PV system in Brisbane (Queensland, Australia). The data was collected between $1^{\text {st }}$ of July 2011 and $30^{\text {th }}$ of June 2012 with 17 sets of 56 tilted (5.5 North) panels and another 4 sets of 60 tilted $\left(2.5^{\circ}\right)$ panels. The result from the field measurements validates the theoretical models and the study also provide valuable information/tools for Australian PV industries and installations (Yan et al. 2013). A study assessed the economic feasibility of the solar PV systems at a campus in New England. The analysis was done based by using actual data from the solar array on campus (Lee et al. 2016). The average payback period of a campus-wide PV system was calculated as primarily 11 years, and was estimated to reduce overall building operating expenses by 8\%. Normazlina et al. (2016), assessed the feasibility of a cogeneration system for a hospital building in Malaysia (Isa et al. 2016). This system consists of a grid connected photovoltaic (PV), battery and fuel cell. The economic parameters used in checking the feasibility of the model includes; renewable fraction, levelized cost of energy (LCOE), total net present cost (TNPC), carbon emission and excess energy production. The simulation result showed that the proposed cogeneration system has the lowest TNPC, LCOE and operating cost which are \$ $106,551,0.091 \$ / \mathrm{kWh}$ and $7245 \$ / \mathrm{yr}$ respectively.

Table 1

Comparison of Solar Irradiance in the three cities

\begin{tabular}{|c|c|c|c|c|c|c|}
\hline \multirow[t]{2}{*}{ Month } & \multicolumn{3}{|c|}{$\begin{array}{c}\text { Fixed axis daily solar radiation } \\
\text { Horizontal } \\
\left(\mathrm{kWh} / \mathrm{m}^{2} / \mathrm{d}\right)\end{array}$} & \multicolumn{3}{|c|}{$\begin{array}{c}\text { Two axis daily solar radiation } \\
\text { Horizontal } \\
\left(\mathrm{kWh} / \mathrm{m}^{2} / \mathrm{d}\right)\end{array}$} \\
\hline & $\begin{array}{l}\text { As- } \\
\text { Sulaymaniy } \\
\text { ah }\end{array}$ & Erbil & Kirkuk & $\begin{array}{l}\text { As- } \\
\text { Sulaymaniyah }\end{array}$ & Erbil & Kirkuk \\
\hline January & 3.90 & 3.51 & 4.00 & 5.21 & 4.66 & 5.25 \\
\hline February & 4.55 & 4.14 & 4.82 & 5.75 & 5.19 & 6.06 \\
\hline March & 5.30 & 5.08 & 5.59 & 6.76 & 6.46 & 7.19 \\
\hline April & 5.60 & 5.61 & 5.78 & 6.98 & 7.02 & 7.30 \\
\hline May & 6.38 & 6.37 & 6.24 & 8.83 & 8.79 & 8.67 \\
\hline June & 7.06 & 7.08 & 7.04 & 10.23 & 10.21 & 10.37 \\
\hline July & 6.84 & 6.92 & 6.82 & 9.76 & 9.88 & 9.86 \\
\hline August & 6.77 & 6.74 & 6.82 & 9.52 & 9.47 & 9.69 \\
\hline September & 6.33 & 6.31 & 6.33 & 8.29 & 8.30 & 8.28 \\
\hline October & 4.93 & 4.91 & 4.77 & 6.49 & 6.52 & 6,16 \\
\hline November & 4.03 & 3.94 & 4.10 & 5.28 & 5.22 & 5.29 \\
\hline December & 3.51 & 3.26 & 3.65 & 4.72 & 4.38 & 4.82 \\
\hline Annual average & 5.44 & 5.33 & 5.50 & 7.33 & 7.18 & 7.42 \\
\hline $\begin{array}{l}\text { Annual total } \\
\text { electricity } \\
\text { export (MWh) }\end{array}$ & $16,987.3$ & $16,726.8$ & 16,948 & 22,777 & 22,454 & 22,758 \\
\hline
\end{tabular}

Other researches that worked on techno-economic analysis and feasibility of PV plants and other system are (Brown et al. 2017; Cai et al. 2017; Freeman et al. 2017; Kassem, Al-Haddad, and Komljenovic 2017; Li et al. 2017; Rehman et al. 2017; Uris, Linares, and Arenas 2017). In all these studies, none worked on Kurdistan region of Iraq in particular, the closest study to this research is a feasibility study of a 10 MW PV power plants in Saudi Arabia (Rehman et al. 2017). The economic feasibility of this project is checked for 44 different sites in the country. Unlike the present study, this research is grid connected and RETScreen software is used for the analysis. The best equity IRR and PBP from all the sites considered is $9.8 \%$ and 17.6 years. This research will provide insight into the profitability of investing in Kurdistan and this can used as template in countries with similar weather data and economic status. This research also provides necessary information for researchers in techno-economic field.

\section{Methodology}

The necessity for more electricity in Kurdistan region of Iraq has been established in section one. Beyond tackling electricity shortage problems, economic viability of a PV power project is important. This will attract investors, reduce carbon emission and tackle power shortage problem. In this research, a $10 \mathrm{MW}$ PV plant will be designed and simulated based on financial parameters for Kurdistan. Three different locations namely; Erbil, 
Kirkuk and As-sulaymmaniyah will be considered. The economic indicators upon which this feasibility and viability measurements are based includes; Simple Payback Period (SPP), Net Present Value (NPV), Internal Rate of Return (IRR), annual life cycle savings, benefitcost ratio and Energy Production Costs. One of the most widely used renewable energy program (RETScreen) is used for the economic analysis. This energy program predicts the economic benefits of using a particular renewable energy for power production based on the input parameters. It should be noted that energy storage is not considered for this research as the proposed PV plant is intended to be grid connected.

\subsection{System Design}

Choosing the right site for a PV plant installation will have a robust effect on its energy production. Also, for simulation purpose, meteorological data availability is very important as it helps to predict the system performance. The three cities in this research are selected based on data availability on the NASA database incorporated by the software developer. These locations are Erbil, Kirkuk and As-sulaymaniyah. The coordinate for these locations respectively is $36^{\circ} 11^{\prime} 28^{\prime \prime} \mathrm{N} 44^{\circ} 0^{\prime} 33^{\prime \prime} \mathrm{E}$ for Erbil, $35^{\circ} 28^{\prime} 0^{\prime \prime} \mathrm{N} \quad 44^{\circ} 119^{\prime} 0^{\prime \prime} \mathrm{E}$ for Kirkuk and $35^{\circ} 33^{\prime} 26^{\prime \prime} \mathrm{N} 45^{\circ} 26^{\prime} 08^{\prime \prime} \mathrm{E}$ for As-sulaymaniyah. It is also important to select the most appropriate slope and azimuth angle to harvest more solar radiation. The azimuth and slope angle for the different locations respectively are 0 and 28 degrees for Erbil, 0 and 30 degrees for Kirkuk and 0 and 28 degrees for Assulaymaniyah. The three locations are characterised with semi-arid climates.

Table 2

PV module specifications

\begin{tabular}{cccc}
\hline Item & Specification & Item & Specification \\
\hline Manufacturer & China Sunergy & Short circuit current & $8.83 \mathrm{~A}$ \\
PV module type/ model & Mono-Si - CSUN200-48M & Frame & Anodized aluminum profile \\
Practical Efficiency & $17.12 \%$ & Mounting dimensions and & thickness \\
Module Efficiency & $15.7 \%$ & Width and Length & $990 \mathrm{~mm} \times 1956 \mathrm{~mm}$ \\
PV Module Rating/ Rated Power & $200 \mathrm{~W}$ & Weight & $23.8 \mathrm{~kg}$ \\
Voltage [@Peak Power] & $35.80 \mathrm{~V}$ & $\begin{array}{c}\text { Standard Operating } \\
\text { Conditions (SOC) }\end{array}$ & $1000 \mathrm{~W} / \mathrm{m} 2, \mathrm{AM} 1.5,25{ }^{\circ} \mathrm{C}$ \\
Current[@PeakPower] & $8.37 \mathrm{~A}$ & $\begin{array}{c}\text { Operating Temperature } \\
\text { Operating Relative }\end{array}$ & $-40{ }^{\circ} \mathrm{C}$ to $+85^{\circ} \mathrm{C}$ \\
Open circuit Voltage. & $44.5 \mathrm{~V}$ & Humidity. & $40 \%$ to $95 \%$ \\
\hline
\end{tabular}

Source: (CSun-Solar 2017)

A summary of the solar radiation data for fixed axis and double axis system is given in Table 1 . In this research, a 200W peak capacity China Sunergy mono-Si-CSUN200$48 \mathrm{M}$ is used in the model design. The panel is common in the market with a practical efficiency is $17.2 \%$ and a module efficiency of $15 \%$ (Table 2 ). The inverters used for this study has an efficiency of $95 \%$ and the capacity is 13,000kW (Abbasoglu, Nakipoglu, and Kelesoglu 2011; Chandel et al. 2014; website 2017). The PV panel is chosen based on the data availability on the simulation software (RetScreen) for this study. The full specifications of the $\mathrm{PV}$-module use in this research is stated in Table 2.

\subsection{Economic Parameters}

The initial costs of the installation, which consists of PV/inverter costs, feasibility studies cost, development cost, balance of system components cost, periodic costs, engineering costs etc. are all required as input parameters. In this research, the financial parameters for the fixed axis and dual axis systems are calculated separately. The initial cost that includes development cost, feasibility and engineering cost are US $\$ 15,184,000$ and US\$19,578,000 for fixed and two-axis respectively. Operation and maintenance (O\&M) cost is an important economic parameter to consider and for this study, the O\&M for fixed and dual axis system are US\$77,000 and US\$98,000 respectively (Abbasoglu, Nakipoglu, and Kelesoglu 2011). A 3.2\% miscellaneous loss is assumed for this simulation based on information from literature (Shiva Kumar and Sudhakar 2015). The energy export rate is $130 \$ / \mathrm{MWh}$ in Iraq currently (No Title n.d.). It is paramount to note that in this research, installation subsidy, feed-in tariff, net metering and other related PV economic policies are not considered as none is in existence in Kurdistan. The main economics parameters used in research are highlighted in table 3 and table 4 .

Table 3

Initial and Periodic Costs of PV Plant

\begin{tabular}{|ccc|}
\hline $\begin{array}{c}\text { Cost Item } \\
\text { Description }\end{array}$ & & \\
\hline Initial Cost Item. & Fixed & Two-Axis \\
Feasibility Study. & US $\$ 1,500$ & US $\$ 1,500$ \\
Development. & US $\$ 2,000$ & US $\$ 4,000$ \\
Engineering. & US $\$ 10,000$ & US $\$ 10,000$ \\
Transmission line & US $\$ 1,000$ & US $\$ 1,000$ \\
Power system and & US $\$ 15,169,500$ & US $\$ 19,561,500$ \\
other components & & \\
Periodic Cost Item. & Fixed & Two-Axis \\
Annual O\&M Cost & $75,000 \$$ & $96,000 \$$ \\
(Annual). & & \\
\hline
\end{tabular}

Table 4

Other Parameters

\begin{tabular}{cc}
\hline Parameters Description & Values \\
\hline Inflation Rate & $1 \%$ \\
Project Life & $25 \mathrm{yrs}$ \\
Corporate income tax & $15 \%$ \\
Interest rate & $4 \%$ \\
Fuel Cost & $0.51 \$ /$ litres \\
\hline
\end{tabular}




\section{Results and Discussions}

In this research, a $10 \mathrm{MW}$ PV plant is simulated based on economic parameters in order to determine its feasibility in Kurdistan region of Iraq. RETScreen simulation program was used for the analysis and the feasibility will be determined based on the economic results. Retscreen program uses the meteorological data of a location to calculate the performance of PV plant. This program considers the effects of ambient temperature and wind on the PV plant performance but does not consider the effect of dust. The PV panel nominal operating cell temperature is also considered as it affects the efficiency of the PV plant. The results presented in this section will be discussed under three sub-sections. The first subsection gives the cash inflow and the energy production from different location while a comparative study of economic indicators like NPV, IRR, SPP etc. are given in sub-section two. Sub-section three will give the benefit of the system to the environments and the greenhouse gas savings.

\subsection{Techno-Economic Feasibility}

The proposed PV plant nominal capacity for all the three locations are the same, hence the land requirement. However, the land requirements for the fixed panels is less compared to the panels with two axis tracking system; $65,317 \mathrm{~m}^{2}$ and $70,621 \mathrm{~m}^{2}$ respectively. The electricity production annually using fixed and two-axis tracking systems respectively for all the locations are; 16,978.3 MWh and 22,777 MWh for As-sulaymaniyah, 16,726.8 MWh and 22,454 MWh for Erbil and 16,948 MWh and $22,758 \mathrm{MWh}$ for Kirkuk. The capacity factors for fixed and dual tracking system in the three locations respectively are $19.4 \%$ and $26 \%$ for As-sulaymaniyah, $19 \%$ and $25.6 \%$ for Erbil and $19.3 \%$ and $26 \%$ for Kirkuk. Other production details including the revenue generated yearly for the three location are given in Table 5.

\subsection{Comparative Economic Feasibility}

One of the main objectives of this research is to compare the PV performance and economic viability for the three different locations. In this subsection, the performance and economic feasibility of the three cities considered will be compared. In comparison, Assulaymaniyah PV plant simulation result had the best electricity produce. This is in agreement with the meteorological data in table 1 . Kirkuk have the secondbest production while Erbil has the least production. The details of the annual electricity production and the life span electricity production is given in table 5 and figure 1.

Table 5

Techno-Economic Results

\begin{tabular}{ccccc}
\hline & & \multicolumn{3}{c}{ Locations } \\
\cline { 3 - 5 } & & As-sulaymaniyah & Erbil & Kirkuk \\
\hline Land Requirement & Fixed & $65,317 \mathrm{~m}^{2}$ & $65,317 \mathrm{~m}^{2}$ & $65,317 \mathrm{~m}^{2}$ \\
& Dual Axis & $70,621 \mathrm{~m}^{2}$ & $70,621 \mathrm{~m}^{2}$ & $70,621 \mathrm{~m}^{2}$ \\
Capacity Factor & Fixed & $19.4 \%$ & $19 \%$ & $19.3 \%$ \\
& Dual Axis & $26 \%$ & $25.6 \%$ & $26 \%$ \\
Annual Electricity & Fixed & $16,978.3 \mathrm{MWh}$ & $16,726.8 \mathrm{MWh}$ & $16,948 \mathrm{MWh}$ \\
Production & Dual Axis & $22,777 \mathrm{MWh}$ & $22,454 \mathrm{MWh}$ & $22,758 \mathrm{MWh}$ \\
Life Span Electricity & Fixed & $424,457.5 \mathrm{MWh}$ & $418,170 \mathrm{MWh}$ & $423,700 \mathrm{MWh}$ \\
Production & Dual Axis & $569,425 \mathrm{MWh}$ & $561,350 \mathrm{MWh}$ & $568,950 \mathrm{MWh}$ \\
Annual Revenue & Fixed & $2,207,178 \mathrm{US} \$ / \mathrm{yr}$ & $2,174,487 \mathrm{US} \$ / \mathrm{yr}$ & $2,203,299 \mathrm{US} \$ / \mathrm{yr}$ \\
& Dual Axis & $2,2961,003 \mathrm{US} \$ / \mathrm{yr}$ & $2,919,002 \mathrm{US} \$ / \mathrm{yr}$ & $2,958,558 \mathrm{US} \$ \mathrm{yr}$ \\
\hline
\end{tabular}

Electricity Exported to the Grid (MWh)

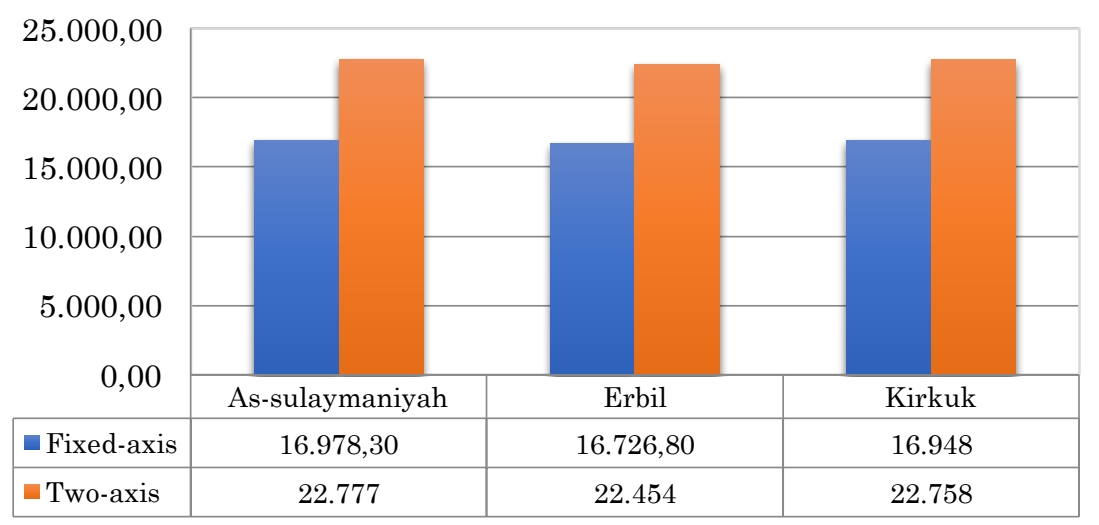

Fig. 1 Comparative chat of electricity exportation

\subsubsection{Payback Period}

Payback period is an indication of the period a project is expected to recoup its initial investment. It utilizes the cash it generates which is calculated using the total initial costs, total annual savings and the total annual costs (but excluding all debt payments). The basic criteria for 
concluding on payback period is that the smaller the payback period, the more desirable the project for investors. (Abbasoglu, Nakipoglu, and Kelesoglu 2011). In this research both the equity payback and simple payback period are considered. The simple payback for fixed/two axis system in the three locations respectively are 7.1/6.9 years for As-sulaymaniyah, 7.2/6.8 years for Kirkuk and Erbil. The equity payback period is between 8.3 and 8.5 for fixed axis and between 8 and 8.1 years for two-axis PV system (Fig. 2).

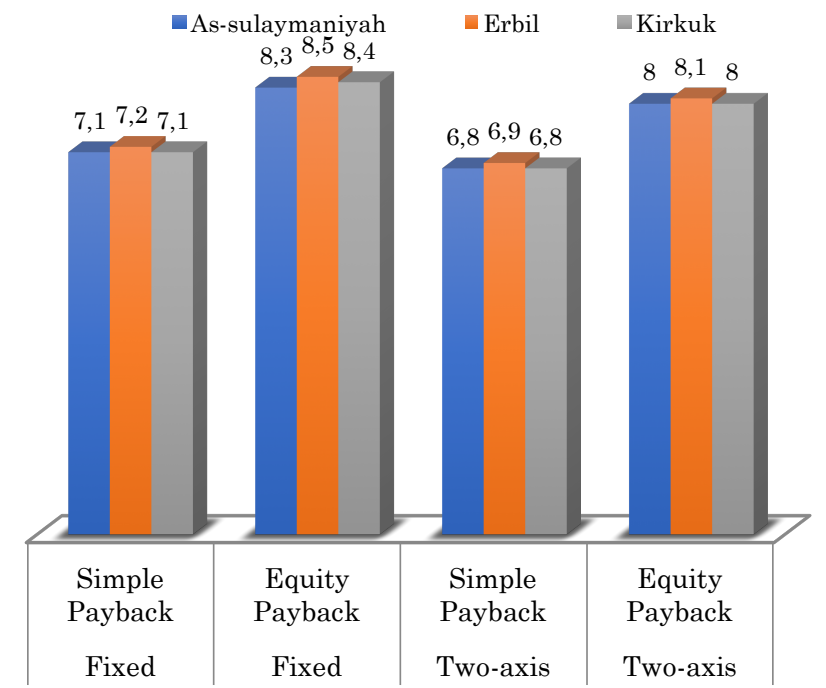

Fig. 2 Comparative chat of Payback Periods (Years)

\subsubsection{Internal Rate of Return (IRR)}

IRR is the interest generated i.e. the time adjusted rate of return by the Project equity over the life of the project. It's calculated by checking the discount rate that would make the net present value of a project amount to zero. A project with an IRR is greater or equal to the discount rate is said to be viable. The Solar PV plant installation considered in this research is feasible for all the locations (Fig. 3) considering the pre-tax and after-tax IRR values for fixed or two axis systems.

\subsubsection{Net Present Value (NPV)}

An investment with a positive NPV will be a profitable one. Also, the higher NPV of a project the higher benefits. NPV presents the worth of a project considering all the future cash flows that is discounted at the discount rate. NPV is a measurement of cumulative profit calculated by subtracting the present values of cash outflows (including initial cost) from the present values of cash inflows over the PV installation life time. NPV can either involved a single investment or a competing investment project. For all the cities considered in this study, the NPVs are greater than zero. This is an indication that the project is feasible for all the locations. Although the difference between As-sulaymaniyah and Kirkuk is not that much in terms of NPV, As-sulaymaniyah still has the greatest NPV and Erbil has the lowest (Fig. 4).

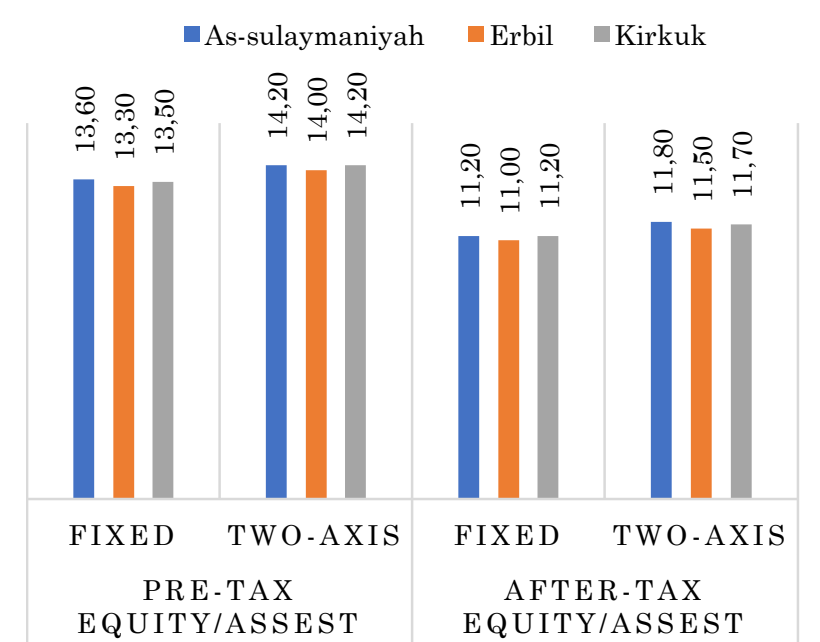

Fig. 3 Pre-tax IRR and After-tax IRR Equity/Assets(\%)

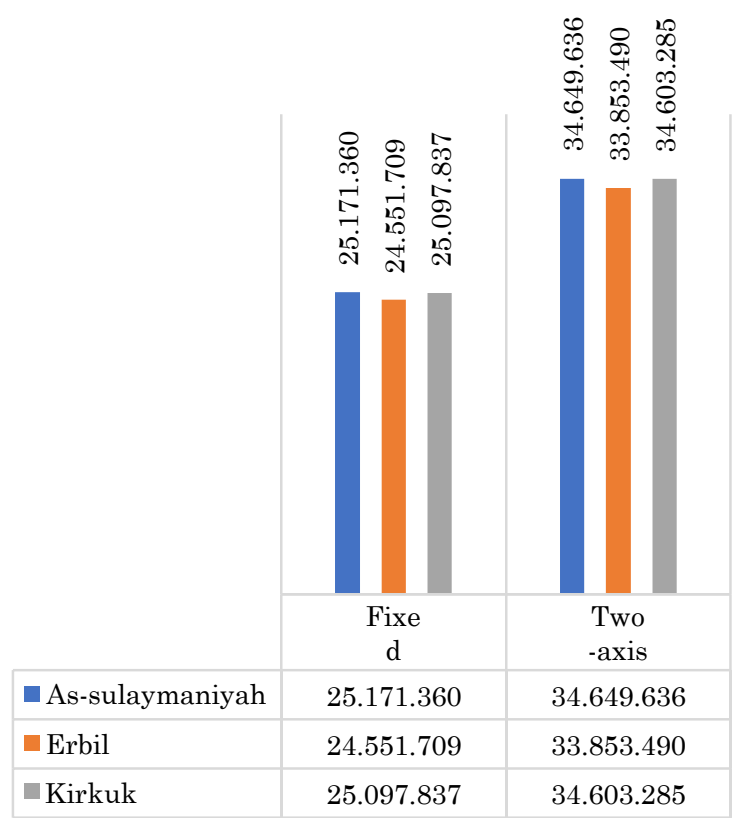

Fig. 41 Comparative chat for the Net Present Values

\subsubsection{Other Financial Parameters}

Other financial parameters like energy production cost (Fig. 6), annual life cycle saving (fig. 5) and benefitcost ratio (Fig. 7) are considered for this study. Benefitcost Ratio (B-C) is an economical ratio that consists of the net benefits to costs of the project. The energy production cost, B-C ratio, and annual life cycle savings for all the cities considered in this research shows that the project is viable. The energy production cost for the three locations ranges from 49.74 US\$/MWh and 52.56 US\$/MWh for both two-axis and fixed systems. The lower the energy production cost of a system, the more feasible the project. Other economic analysis results are given in Table 7. 
$\square$ Fixed $\square$ Two-axis

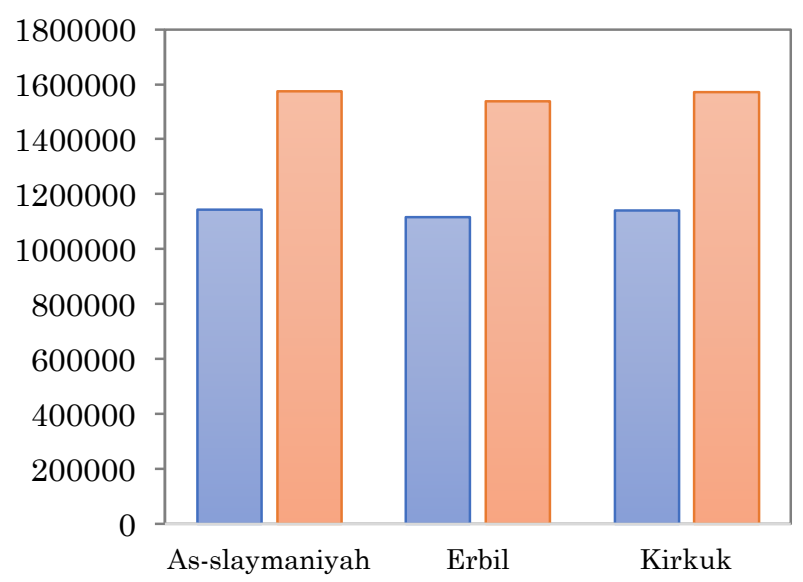

Fig. 5 Annual Life Cycle Savings Analysis Result

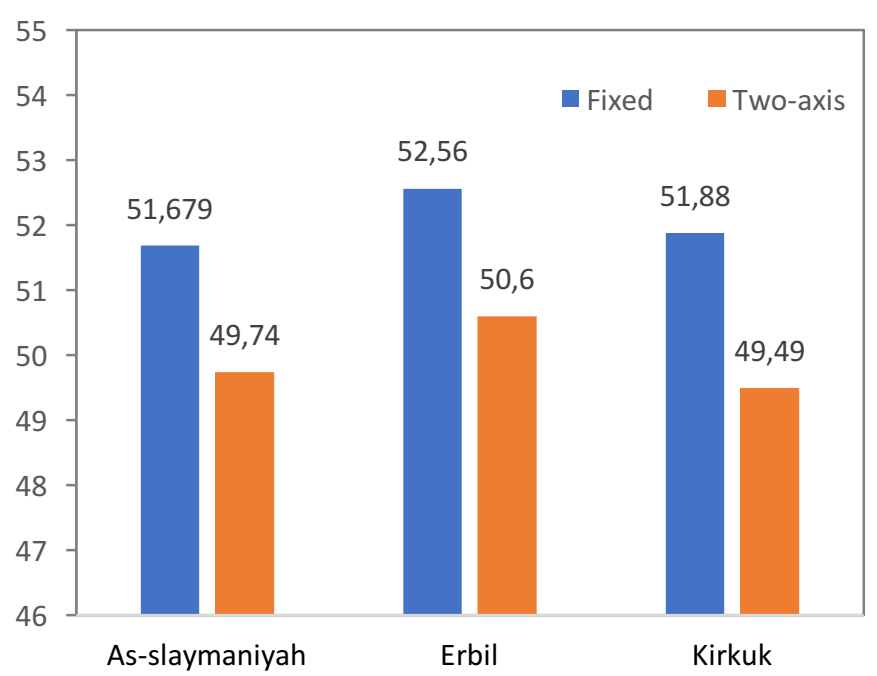

Fig. 6 Energy Production Cost (US\$/MWh) Analysis Result

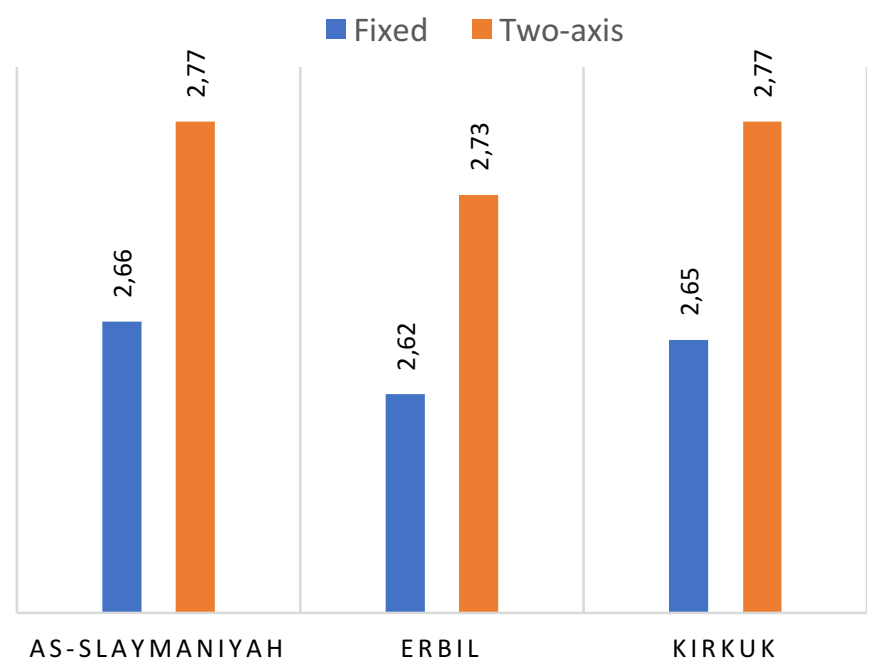

Fig. 7 Benefit-Cost Ratio Analysis Result (\%)
Table 6

Other Economic Analysis Results

\begin{tabular}{lcll}
\hline \multicolumn{4}{c}{ Annual life cycle savings (US\$/yr) } \\
\hline Locations & As-slaymaniyah & Erbil & Kirkuk \\
Fixed & $1,142,950$ & $1,114,813$ & $1,139,611$ \\
Two-axis & $1,573,327$ & $1,537,177$ & $1,571,223$ \\
& Energy Production cost (US\$/MWh) \\
\hline Locations & As-slaymaniyah & Erbil & Kirkuk \\
Fixed & 51.679 & 52.56 & 51.88 \\
Two-axis & 49.74 & 50.6 & 49.49 \\
\multicolumn{4}{c}{ Benefit-Cost Ratio } \\
Locations & As-slaymaniyah & Erbil & Kirkuk \\
Fixed & 2.66 & 2.62 & 2.65 \\
Two-axis & 2.77 & 2.73 & 2.77 \\
\hline
\end{tabular}

\subsection{Fuels/Greenhouse Gas Emission Saving}

One main advantage of renewable energy over fossil fuels is the reduction in Green House Gas (GHG) emission. These GHGs include; carbon dioxide $\left(\mathrm{CO}_{2}\right)$, nitrous oxide $\left(\mathrm{N}_{2} \mathrm{O}\right)$, methane $\left(\mathrm{CH}_{4}\right)$, ozone $\left(\mathrm{O}_{3}\right)$ and several classes of halo carbons. The most relevant GHGs to energy projects' analysis are methane $\left(\mathrm{CH}_{4}\right)$, carbon dioxide $\left(\mathrm{CO}_{2}\right)$ and nitrous oxide $\mathrm{N}_{2} \mathrm{O}$. These gases were considered in GHG emission reduction analysis. The yearly GHG emission savings (in $\mathrm{tCO}_{2}$ ) for fixed systems for As-sulaymaniyah, Erbil and Kirkuk are 17,027, 16,774 and 16,997 respectively. Using a two-axis tracking system increases these values (Table 7). The fuel oil saving for each of the locations and tracking systems are well over 1,000,000 litres annually (Table 7). This fuel saving is also calculated in terms of the equivalent cars and light trucks that will not be used yearly and the result is shown in Table 7 .

\section{Conclusions}

In this research, the use of a renewable energy source to meet electricity demand was evaluated economically. A 10 MW PV plant was designed and simulated for three different locations in Kurdistan, Iraq. RETScreen software was used for the simulation and analysis. This section presents the conclusion from the analysis of this systems based on economic terms like NPV, IRR, payback period and other economic parameters. Installing a 10 MW PV plant in all the three locations (As-sulaymaniyah, Erbil, Kirkuk) considered is generally feasible. The simple payback period for this installation in all the locations considered ranges from 6.8 years to 7.2 year. The payback period is quite high in comparison to similar installations in developed countries that are achieving simple payback periods of 3 years or less. The relatively high payback period is due to the low electricity tariff for Iraq (130 $\$ / \mathrm{MWh}$ ) and the absence of PV plant incentives. Installing a PV plant with two-axis tracking system gave the lowest simple payback period (6.8 years).

Considering other economic indicators; IRR, NPV, annual life cycle savings and BCR, the project is highly feasible. The NPV for all the cases considered indicates that the project (s) are viable. Installing a two-axis $10 \mathrm{MW}$ $\mathrm{PV}$ plant in As-sulaymaniyah will save as much as 
US $\$ 1,573,327$ per year. In terms of benefit cost ratio, Kirkuk and As-sulaymaniyah gives the best result (2.77\%) among the three sites considered. The energy production cost for PV plant is in all the three locations considered in this research is between $51.68 \$ / \mathrm{MWh}$ and $52.56 \$ / \mathrm{MWh}$ (Fig. 7). This is far cheaper than the current electricity tariff of $130 \$ / \mathrm{MWh}$. Also, this is an indicator that the use of PV instead of "generator devices" in Kurdistan is economical feasible and viable. Generator devices are about 10 times higher than the current electricity tariff which is high than the PV plant energy production cost. This will also reduce the environmental concerns raised from the use of fossil fuels in Kurdistan. Using a two-axis tracking system is generally economically better than a fixed system. According to the meteorological data, Assulaymaniyah has the highest solar potential hence the best economic analysis results. Installing 10 to $20 \mathrm{MWp}$ PV plant with either fixed or two-axis system will solve part of the existing power problems in Kurdistan especially in rural areas.

Table 7

Greenhouse Gases Savings

\begin{tabular}{llllll}
\hline Location & \multicolumn{2}{c}{ GHG Savings } & \multicolumn{2}{c}{ Fossil Fuel Savings } & \multicolumn{1}{c}{ Fuel Cost } \\
\cline { 2 - 6 } & $\begin{array}{l}\text { GHG savings } \\
\text { per yr (tCO2) }\end{array}$ & $\begin{array}{l}\text { GHG saving } \\
\text { over 25 years } \\
\text { (tCO2) }\end{array}$ & $\begin{array}{l}\text { Fuel oil savings } \\
\text { (litres) }\end{array}$ & $\begin{array}{l}\text { Equivalent of cars } \\
\text { \& light trucks not } \\
\text { used yearly }\end{array}$ & $\begin{array}{l}\text { Using the fuel cost in } \\
\text { dollars for Iraq (0.51 } \\
\text { dollars/litre) }\end{array}$ \\
\hline $\begin{array}{l}\text { As-sulaymaniyah (fixed) } \\
\text { As-sulaymaniyah (two- } \\
\text { axis) }\end{array}$ & 17,027 & 425,661 & $1,520,508$ & 3,118 & $775,459.08$ \\
Erbil (fixed) & 22,842 & 571,039 & $2,039,852$ & 4,184 & $1,040,324.52$ \\
Erbil (two-axis) & 16,774 & 419,357 & $1,498,029$ & 3,072 & $763,994.79$ \\
Kirkuk (fixed) & 22,518 & 562,939 & $2,010,925$ & 4,124 & $1,025,571.75$ \\
Kirkuk (two-axis) & 16,997 & 424,913 & $1,517,821$ & 3,113 & $774,088.71$ \\
\hline
\end{tabular}

Considering Iraq as a country that emits sizeable amount of greenhouse gases, implementing this project abate some considerable emissions into the atmosphere. Reduction of GHG emission is currently a global issue and all nations are trying to achieve. Installing a $10 \mathrm{MW}$ PV plant in any of the three locations considered will save at least 419,357 tonnes of $\mathrm{CO}_{2}$ equivalence emission from the atmosphere. This will also increase energy security, sustainability and equity of the country thereby increasing its political status in global energy ranking. Finally, this study provides basics for other technoeconomic analysis about PV plant. Data and results from this research can be adopted in similar application. It will also serve as a bedrock research for PV plant application research in Kurdistan.

Based on the analysis, results/discussions and conclusion of this research, the following are recommended:

- Research should be done on the possibility of installing a PV system with a higher capacity.

- Analyzing and comparing the feasibility of other PV technologies like; solar PV-T and CPV should be done to determine the most suitable technology.

- The country of Iraq should introduce different renewable energy policies (feed-in-tariff and netmetering) that will enhance/encourage PV installation.

\section{References}

Sayigh, A.A.M. (1978). Effect of Dust on the Flat-Plate Collectors. In International Solar Energy Society Congress, New Delhi, India.

Abbasoglu, S., Nakipoglu, E., and Kelesoglu, B. (2011). Viability Analysis of 10 MW PV Plant in Turkey. Energy Education Science and Technology Part A: Energy Science and Research 27(2), 435-46.

Abdul-Wahid, S., Ali Mahdy, N. and Godu, A.H. (2010). Calculation and Applications of Net Solar Radiation in
Iraq. Al-qadisiyah for pure science 15(1), 1-30.

Abdulrahman, A., Abdullah, S., and Danial, C. (2014). Minimizing Electricity Shortages in Koya City in Iraq Using Photo Voltage Gird System Simulation. International Journal of Computer Science and Electronics Engineering 2(2), 88-91.

Abolhosseini, S., Heshmati, A., Altmann, J. (2014). A Review of Renewable Energy Supply and Energy Efficiency Technologies. IZA Discussion Paper (8145), 1-35.

Akinyele, D. O. (2017). Environmental Performance Evaluation of a Grid-Independent Solar Photovoltaic Power Generation (SPPG) Plant. Energy 130, 515-29.

Akinyele, D. (2017). Techno-Economic Design and Performance Analysis of Nanogrid Systems for Households in EnergyPoor Villages. Sustainable Cities and Society 34, 335-57.

Al-Karaghouli, A. and Kazmerski, L.L. (2010). Optimization and Life-Cycle Cost of Health Clinic PV System for a Rural Area in Southern Iraq Using HOMER Software. Solar Energy 84(4), 710-14.

Asaee, S.R., Nikoofard, S., Ugursal, V.I. and Morrison, I.B. (2017). Techno-Economic Assessment of Photovoltaic (PV) and Building Integrated Photovoltaic/Thermal (BIPV/T) System Retrofits in the Canadian Housing Stock. Energy and Buildings 152, 667-79.

Boussetta, M., El Bachtiri, R., Khanfara, M. and El Hammoumi, K. (2017). Assessing the Potential of Hybrid PV-Wind Systems to Cover Public Facilities Loads under Different Moroccan Climate Conditions. Sustainable Energy Technologies and Assessments 22, 74-82.

Brown, M.A., Kim, G., Smith, A.M. and Southworth, K. (2017). Exploring the Impact of Energy Efficiency as a Carbon Mitigation Strategy in the U.S. Energy Policy 109, 249-59.

Cai, J., Ji, J.,Wang, W., Zhou, F. and Yu, B. (2017). A Novel PV/TAir Dual Source Heat Pump Water Heater System: Dynamic Simulation and Performance Characterization. Energy Conversion and Management 148, 635-45.

Chandel, M., Agrawal, G.D., Mathur, S. and Mathur, A. (2014). Techno-Economic Analysis of Solar Photovoltaic Power Plant for Garment Zone of Jaipur City. Case Studies in Thermal Engineering, 2, 1-7.

CSun-Solar. (2017). http://www.csunsolar.com/fileadmin/dateiablage/media/datasheets/p- 
mod/en/CSUN305-72P_ENG.pdf (June 1, 2017).

Dihrab, S.S., and Sopian, K. (2010). Electricity Generation of Hybrid PV/Wind Systems in Iraq. Renewable Energy 35(6), 1303-7.

Freeman, J., Guarracino, I., Kalogirou, S.A. and Markides, C.N. (2017). A Small-Scale Solar Organic Rankine Cycle Combined Heat and Power System with Integrated Thermal-Energy Storage. Applied Thermal Engineering $127,1543-54$.

Government, Ministry of Planning- Kurdistan Region. 2013. Kurdistan Region of Iraq 2020: A Vision for the Future. http://www.iraqjccme.jp/pdf/archives/krg_2020_english.pdf.

Grover, S. 2007. Energy, Economic, and Environmental Benefits of the Solar America Initiative. Oregon, USA: National Renewable Energy Laboratory.

IEA. (2016). Energy Outlook 2016. IEA. https://www.iea.org/newsroom/news/2016/november/world -energy-outlook-2016.html (July 20, 2017).

Isa, N.M., Das, H.S., Tan, C.W., Yatim, A.H.M., Lau, K.Y. (2016). A Techno-Economic Assessment of a Combined Heat and Power Photovoltaic/Fuel Cell/Battery Energy System in Malaysia Hospital. Energy 112, 75-90.

Kassem, A., Al-Haddad, K., and Komljenovic, D. (2017). Concentrated Solar Thermal Power in Saudi Arabia: Definition and Simulation of Alternative Scenarios. Renewable and Sustainable Energy Reviews 80, 75-91.

Kazem, A.A., Chaichan, M.T. and Kazem, H.A. (2014). Dust Effect on Photovoltaic Utilization in Iraq: Review Article. Renewable and Sustainable Energy Reviews 37, 734-49.

Khorasanizadeh, H., Mohammadi,K. and Mostafaeipour, A. (2014). Establishing a Diffuse Solar Radiation Model for Determining the Optimum Tilt Angle of Solar Surfaces in Tabass, Iran. Energy Conversion and Management 78, 805-14.

Lee, J., Chang,B., Aktas, C. and Gorthala, R. (2016). Economic Feasibility of Campus-Wide Photovoltaic Systems in New England. Renewable Energy 99, 452-64.

Li, Y., Chen, X.M., Zhao, B.Y., Zhao, Z.G., Wang, R.Z. (2017). Development of a PV Performance Model for Power Output Simulation at Minutely Resolution. Renewable Energy 111, 732-39.

www.doingbusiness.org/getting-electricity (June 1, 2017).

Patil, V.R., Biradar, V.I., Shreyas, R., Garg, P., Orosz,M.S. and Thirumalai,N.C. (2017). Techno-Economic Comparison of Solar Organic Rankine Cycle (ORC) and Photovoltaic (PV) Systems with Energy Storage. Renewable Energy 113,
$1250-60$.

Ramirez-Sagner, G., Mata-Torres, C., Pino, A. and Escobar, R.A. (2017). Economic Feasibility of Residential and Commercial PV Technology: The Chilean Case. Renewable Energy 111,332-43.

Rashid, R.H.M. (2014). The Use of Water for Sustainable Rural Development: A Case Study in the Kurdistan Regional Government. University of Agricultural Sciences and Veterinary Medicine Cluj-Napoca, Romania.

Rashwan, S.S., Shaaban, A.M. and Al-Suliman, F. (2017). A Comparative Study of a Small-Scale Solar PV Power Plant in Saudi Arabia. Renewable and Sustainable Energy Reviews 80, 313-18.

Rehman, S., Ahmed, M.A., Mohamed, M.H. and Al-Sulaiman, F.A. (2017). Feasibility Study of the Grid Connected $10 \mathrm{MW}$ Installed Capacity PV Power Plants in Saudi Arabia. Renewable and Sustainable Energy Reviews 80, 319-29.

Rehman, S., Alam, Md. M., Meyer, J.P. and Al-Hadhrami, L.M. (2012). Feasibility Study of a Wind-Pv-Diesel Hybrid Power System for a Village. Renewable Energy 38(1), 25868.

Salehin, S., Ferdous, M.T., Chowdhury, R.M., Shithi, S.S., Rofi, M.S.R.B., Mohammed, M.A. (2016). Assessment of Renewable Energy Systems Combining Techno-Economic Optimization with Energy Scenario Analysis. Energy 112, $729-41$.

Shahzad, M.K., Zahid, A., Ur-Rashid, T., Rehan, M.A., Ali, M., Ahmad, M. (2017). Techno-Economic Feasibility Analysis of a Solar-Biomass off Grid System for the Electrification of Remote Rural Areas in Pakistan Using HOMER Software. Renewable Energy 106, 264-73.

Kumar, B.S, and Sudhakar,K (2015). Performance Evaluation of 10 MW Grid Connected Solar Photovoltaic Power Plant in India. Energy Reports 1, 184-92.

Uris, M., Linares, J.I. and Arenas,E. (2017). Feasibility Assessment of an Organic Rankine Cycle (ORC) Cogeneration Plant (CHP/CCHP) Fueled by Biomass for a District Network in Mainland Spain. Energy 133, 969-85.

website. 2017. "Solar Trade." https://www.solartraders.com (June 1, 2017).

Yan, R., Saha, T.K., Meredith, P. and Goodwin, S. (2013). Analysis of Yearlong Performance of Differently Tilted Photovoltaic Systems in Brisbane, Australia. Energy Conversion and Management 74, 102-8. 